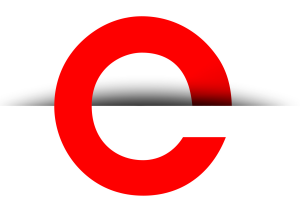

U T S

e PRES S
PORTAL Journal of Multidisciplinary International Studies

Vol. 17, No. 1/2

Jan 2021

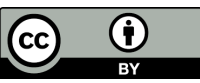

(c) 2021 by the author(s). This is an Open Access article distributed under the terms of the Creative Commons Attribution 4.0 International (CC BY 4.0) License (https:// creativecommons.org/ licenses/by/4.0/), allowing third parties to copy and redistribute the material in any medium or format and to remix, transform, and build upon the material for any purpose, even commercially, provided the original work is properly cited and states its license.

Citation: Averis, K. 2021 Ni una menos: Colombia's Crisis of Gendered Violence during the Covid-19 Pandemic. PORTAL Journal of Multidisciplinary International Studies, 17:1/2, 91-96. http:// dx.doi.org/10.5130/pjmis. v17i1-2.7367

ISSN 1449-2490 | Published by UTS ePRESS | http://epress. lib.uts.edu.au/ojs/index.php/ portal
ESSAY

\section{Ni una menos: Colombia's Crisis of Gendered Violence during the Covid-19 Pandemic}

\author{
Kate Averis \\ Corresponding author: Kate Averis, Universidad de Antioquia, Calle 67 Número 53-108 P.O BOX \\ 1226, Medellin, Colombia. katherine.averis@udea.edu.co \\ DOI: http://dx.doi.org/10.5130/pimis.v17i1-2.7367 \\ Article History: Received 13/08/2020; Accepted 09/11/2020; Published 28/01/2021
}

\begin{abstract}
In spite of the shared nature of the global suffering caused by the pandemic, the lockdown imposed to reduce the spread of Covid-19 has exposed and exacerbated the crisis of gendered violence in Colombia. While many countries around the globe have reported an increase in gendered violence during the pandemic, Colombia's lockdown has taken place in a context of already high rates of violence towards women and girls. Such an environment has proven propitious for the propagation of incidents of gendered violence throughout all strata of society, with indigenous women and girls, and those living in precarious conditions, in particularly vulnerable to often life-threatening circumstances. This article charts the particular impact of the lockdown on gendered violence in Colombia and discusses the reactions of feminists, journalists, academics, writers and artists.
\end{abstract}

\section{Keywords}

Gender-based violence; Colombia; Covid-19; Lockdown; Feminisms

In spite of the shared nature of the global suffering caused by the Covid-19 pandemic, the lockdown imposed to reduce the spread of the new strain of coronavirus has exposed and exacerbated the current crisis of gendered violence in Colombia. While UN Women has reported an emerging global 'shadow pandemic' of violence against women and girls coincident with the spread of Covid-19, Colombia's lockdown has taken place in a context of already 'pandemic and structural' violence against women and girls (Atencio et al. 2019). This article charts the particular impact of the lockdown on women and girls vulnerable to gendered 
violence in Colombia and discusses the reactions of - the predominantly female-feminists, journalists, academics, writers and artists who have responded to this crisis.

The many and profound disruptions occasioned by the Covid-19 pandemic have occurred in a context of already high rates of gendered violence in Colombia (as documented by Graciela Atencio et al. 2019). These have been receiving increasing attention in recent decades, from the codification of equality between women and men in the 1991 Constitution to the passing of laws in 2008 and 2015 that enshrine mechanisms of recognition, prevention and punishment of violence against women and girls. Ana Güezmes, the representative of UN Women in Colombia, has called for the effective enforcement of these laws in light of the fact that violence against women and girls in Colombia has increased in recent years (Sarralde 2018). This appeal has been echoed by feminist, women's and human rights organisations throughout the country, from the National Women's Network to the Colombian branch of the Women's International League for Peace and Freedom, Limpal Colombia, who have consistently warned of the heightened danger faced by women and girls in Colombia, and repeatedly denounced the government's failure to ensure their safety.

Gendered violence in Colombia is not limited to any particular age range, with assaults recorded against

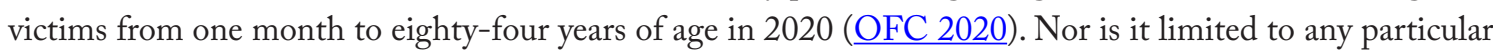
socio-economic background. While women and girls who are indigenous, LGBTQI+ or living in precarious social and economic circumstances are proven to be particularly vulnerable to gendered violence, a number of recent cases show gendered violence to affect women throughout society: in academia, as illustrated by 131 students' accusations of sexual harrassment at the Universidad Distrital Francisco José de Caldas (El Espectador 2020); in politics, with the denunciation of regional mayors Vicente Young and Daniel Quintero for sexual abuse (Sepúlveda 2020; Bohórquez and Urbina 2020); and in the arts, with the publication of the testimonies of eight women who describe being sexually harassed or abused by the filmmaker Ciro Guerra (Ruiz-Navarro and Londoño 2020).

Where the perpetrator of a reported case of sexual violence is identifiable, this is most frequently someone known to the victim, be it through personal, family, social or occupational connections, although a significant proportion of such crimes are also committed against women who are prominent in their communities for carrying out roles of organisation and leadership for which they are targeted by both State and non-State actors ( $\underline{\mathrm{OFC} 2020})$. Güezmes notes a marked increase in recent years in intimidation and attacks against female community leaders, emphasising the gendered nature of the violence with which they are targeted which often takes the form of sexual violence and threats of violence to other (particularly female) members of their families (Sarralde 2018).

The contributing factors behind the particular context of gendered violence in Colombia that have been exacerbated during the period of lockdown are many, complex and interrelated. In addition to the structural criminality in operation in many regions that effectively creates what the Argentine feminist anthropologist Rita Segato (2016) has described as a 'second State' that allows and cultivates a 'low-level war' against women and girls, Colombia's history of armed conflict also plays an important role in intensifying violence against women and girls, who have more frequently been at the receiving end of physical and sexual violence.

Further exacerbating this historical context of gendered violence is a political context of misogyny from local to national level, as illustrated by the statement of regional town councillor, Ramón Cardona, that 'women, like laws, are to be violated' (Martínez 2017) and the former Defence Minister, Luis Carlos Villegas' dismissal of the systemic assassination of community leaders and human rights defenders in Colombia as driven by 'líos de faldas' [skirt-chasing] (VA 2017). Such institutional misogyny is echoed in the speech acts of everyday sexism, where female professionals are often referred to by their forename while surnames are used for their male colleagues, and the term 'mujer' [woman] is frequently discarded when referring to women in preference for 'niña' [young girl] or 'vieja' [old woman], contributing to an 
U T S

e PRES S

environment in which women's achievements are downplayed or go unrecognised. The reproduction of such misogyny in Colombia's notoriously weak institutions translates into a failure to investigate and prosecute the vast majority of incidents of gendered violence, with only 17 per cent of cases of sexual abuse charged, and only 5 per cent tried (Sarralde 2018). For the members of the Feminist Anti-Militarist Network who have created and manage the Observatory of Femicides in Colombia (OFC), these statistics indicate that most perpetrators enjoy virtual impunity for crimes of physical and sexual violence against women and girls (Atencio et al. 2019).

These circumstances that produce, enable and authorise violence against women and girls have been exacerbated by the lockdown imposed to contain the spread of COVID-19 in Colombia, pronounced on 20 March and partially lifted on 1 September. Statistics that reveal the incidence of violence against women and girls during this period capture only the incidents that have been reported or where victims have sought support. Given the reluctance of victims to report and the lack of systematic institutional data collection (OFC 2020), statistical data tell only a partial story of the increase of gendered violence during lockdown. They nevertheless indicate a sharp increase, with an $8.6 \%$ rise in femicides in the capital, Bogotá, and a $230 \%$ surge in calls to the city's municipal helpline for women at risk of violence (Torres n.d.) confirming, for the National Women's Network, that 'the home is the most dangerous place for women, where most rapes and murders occur' (NWW n.d.). Dora Saldarriaga, Medellín town councillor, cites 5,717 reports of domestic violence made in the period from 20 March to 8 May 2020, up from 1,782 in the same period in 2019, calling for the declaration of a humanitarian crisis of violence against women on behalf of Estamos Listas [We're Ready] Colombia's only women's political party (Noticias Caracol 2020). Such a dramatic increase is not limited to Colombia in the Latin American context and similar hikes have been observed, most markedly, where support and services have been reduced, as seen, for example, in Mexico ( $\underline{\text { Aquino }}$ 2020).

Compounding the lack of conclusive data that would reveal the full extent of gendered violence in Colombia, both during and preceding the lockdown, is its inconsistent and often sensationalised media coverage. In her report on the 150 femicides recorded in the first half of 2020, Salomé Gómez-Upegui highlights the fact that most people will not be able to name even five of these women due to the selective nature of media reports on gendered violence which she describes as largely consisting of the repetition of reports produced by NGOs that cite accumulated cases and new records surpassed without telling the individual stories behind the statistics. The effect of such selective reporting is, for Gómez-Upegui, that many believe that gendered violence in Colombia is limited to isolated cases rather than due to systemic factors. In an attempt to document the systemic nature of gendered violence, Natalia Arenas (2020) has recorded the stories of forty-two women and girls murdered during the first sixty-eight days of the lockdown in Colombia, relying on regional newspapers and women's organisations as sources. While the national newspaper, El Tiempo, has dedicated reporting on sexual violence against women and children since 2009 in the 'No es hora de callar' [Now is not the time to remain silent] campaign directed by Jineth Bedoya, it has largely been feminist journalists in smaller outlets that have undertaken the task.

In addition to female journalists, prominent female academics in Colombia have reacted publicly to the crisis of gendered violence during the lockdown. Judith Nieto López, professor at the University of Antioquia, decried the indifference of local, regional and national governments to the increasing rates of femicide, denouncing the 'barbarian' State that permits the murder of women and girls and the 'reigning patriarchy' that demands women and girls' compliance to certain cultural expectations (2020). Nieto López also highlights the particular vulnerability of women and girls of Colombia's 115 indigenous groups by dedicating her intervention to the thirteen-year-old girl of the Emberá Katío nation who survived rape by seven members of the Colombian army in June, an institution with a record of sexual abuse of, in particular, indigenous women and girls (Bedoya n.d.). Lucía González, member of the Truth Commission formed to facilitate the process of peace and reconciliation in the implementation of the historic peace treaty signed by 
U T S

e PRES S

the Colombian government in 2016, argues for a reconsideration of the seven soldiers' act not as attributable to monstrosity or pack mentality but as a symptom of a hegemonic patriarchy in need of deconstruction in order for women and girls' humanity, subjectivity and bodily integrity to be recognised and respected. She also argues for a true valorisation of the diversity of the Colombian population-which includes significant Afro-Colombian and indigenous ethnic minorities-in order to combat the intersectional compounding of suffering, and for policies and governance that prevent deprivation converting into violence.

Latin American feminist organisations beyond Colombia have also been urgently calling attention to the crisis of gendered violence during lockdown in the continent, most notably Ni una menos, the now continental movement against gender-based violence that originated in Argentina in 2015. LASTESISthe Chilean feminist art collective that drew worldwide attention to the complicity of the State in gendered violence in Latin America (and beyond) with 'Un violador en tu camino' [A rapist in your path] in November 2019- has drawn attention to the fact that the State mandate to remain at home confined many women and girls to the very space that is the most dangerous for them with little if any provision for their protection. The unrelenting rhythm, focus on female bodies contorted into confined domestic spaces and banality of the culinary actions and utensils featured in the video 'Nos roban todo, menos la rabia' [They steal everything from us but rage], released by LASTESIS on 22 June during the Chilean lockdown, depicts women quite literally 'atrapadas sin salida con las armas homicidas' [trapped with the murder weapons and with no way out].

Female artists have long played a key role in pushing back against the high rates of gendered violence in Latin America, and feminist writers in Colombia are a particular case in point. Laura Restrepo, one of Colombia's foremost writers, has consistently addressed the most pressing political and social issues affecting Colombians, with recent publications focusing on partner violence and child abuse (2016; 2018). Adopting a journalistic approach in her fictional writing that is based on investigation and interviews, Restrepo makes up for what has been occluded from the historical record in novels that emphasise the contexts and impacts rather than the acts of violence. In Los Divinos [The Divines] (2018), she attempts to imagine the circumstances that led Rafael Uribe Noguera, from a well-connected Bogotá family, to kidnap, torture, abuse and murder a seven-year-old indigenous Yanakuna girl, Yuliana Samboní, in 2016. In a pointed effort to avoid recreating the violence perpetrated against Yuliana, Restrepo focuses her narrative on the privileged social and economic circumstances of the perpetrator, highlighting the intersection of sexism, racism and classism that produced and enabled such a crime.

Restrepo is one of many female writers, filmmakers and artists who have reacted to the crisis of gendered violence in Colombia, from Laura Mora to Doris Salcedo. Salcedo, whose sculptures and installations have long focused on the violence committed against women during Colombia's historical armed conflict, created her 2018 installation, Fragmentos [Fragments] from 37 tonnes of firearms that were melted and recast as slabs whose moulds were beaten and shaped by women who suffered physical and sexual violence during the conflict. The resulting 1,296 slabs were then laid to form the floor of an exhibition space located one block from the presidential palace in Bogotá. The Colombian president, Iván Duque, declined the invitation to attend the inauguration of Salcedo's 'counter-monument' to the signing of the historic peace deal signed between the Colombian government and the FARC [Revolutionary Armed Forces of Colombia] in 2016, illustrating the governmental indifference that feminists such as Judith Nieto López have decried.

The current crisis of gendered violence in Colombia thus stems from a history of violent conflict, an institutional and social context of misogyny, and entrenched gendered, ethnic and class hierarchies that have compounded the sanitary, economic and security tensions fostered by lockdown. While it is a commonplace to hear in press conferences and media reports that COVID-19 does not discriminate on the basis of class, ethnicity or gender in its capacity to spread rapidly through the community, its impact has been vastly divergent for differently situated groups and individuals in terms of infection rates, the repercussions of preventive and containment measures, and their economic consequences. For women and girls who were 
U T S

e PRES S already vulnerable to gendered violence, confinement to the home amidst a current and historical lack of prevention, sanction and reparation of gendered violence has proven catastrophic. Women and girls in Colombia will need greater support at all levels of society if the nation is to play a role in achieving the UN Women goal of the global elimination of gender-based violence by 2030 .

\section{References}

Aquino, E. 2020, 'Feminicidios, Delitos Sexuales y Violencia Familiar Aumentaron en Junio,' Animal Politico, 22 July. Online, available: https://www.animalpolitico.com/2020/07/feminicidios-delitos-sexuales-violencia-familiar-aumentanjunio/ [Accessed 12 August 2020].

Atencio, G. et al. 2019, Paren la guerra contra las mujeres: contribuciones al análisis feminista de la violencia feminicida en Colombia. Online, available: http://redfeministaantimilitarista.org/ [Accessed 12 August 2020]

Arenas, N. 2020, ‘42 Mujeres Asesinadas en 68 días de Cuarentena’, cerosetenta. Online, available: https://cerosetenta. uniandes.edu.co/en-cuarentena-una-mujer-fue-asesinada-casi-que-cada-dia-de-por-medio/ [Accessed 12 August 2020].

Bedoya, J. n.d., 'No es hora de callar', El Tiempo. Online, available: https://www.eltiempo.com/noticias/no-es-hora-decallar [Accessed 12 August 2020].

Bohórquez, V. \& Urbina, M. 2020, 'El silencio del Alcalde de Medellín frente a Denuncias de Violencia Sexual que lo Señalan,' El Espectador, 21 June. Online, available: https://www.elespectador.com/opinion/el-silencio-del-alcalde-demedellin-frente-a-denuncias-de-violencia-sexual-que-lo-senalan/ [Accessed 12 August 2020].

El Espectador 2020, ‘Claudia López Pide Investigación contra Profesor Señalado de Acoso Sexual en la U. Distrital,' 17 July. Online, available: https://www.elespectador.com/noticias/bogota/claudia-lopez-pide-investigacion-contra-profesorsenalado-de-acoso-sexual-en-la-u-distrital/ [Accessed 12 August 2020].

Gómez-Upegui, S. 2020, ‘Qué Feminicidios Sí Son Noticia?, cerocetenta, 12 July. Online, available: https://cerosetenta. uniandes.edu.co/que-feminicidios-si-son-noticia/ [Accessed 12 August 2020].

González, L. 2020, 'Los Soldados que Violaron a la Niña Embera Son el Síntoma que no Queremos Ver,' „Pacifista!, 30 June. Online, available: https://pacifista.tv/notas/los-soldados-que-violaron-a-la-nina-embera-son-el-sintoma-que-noqueremos-ver/ [Accessed 12 August 2020]

LasTesis 2019, 'Un violador en tu camino,'20 November. Online, available: https://www.youtube.com/ watch?v=9sbcU0pmViM [Accessed 12 August 2020].

LasTesis 2020, 'Nos roban todo, menos la rabia,'22 June. Online, available: https://www.youtube.com/ watch?v=HGIPmdexu9I [Accessed 12 August 2020].

Limpal Colombia 2020, 'Las Niñas y Adolescentes en Colombia Están en Peligro,'10 July. Online, available: https:// www.limpalcolombia.org/es/informate/comunicados/42-las-ninas-y-adolescentes-en-colombia-estan-en-peligro [Accessed 12 August 2020].

Martínez, P. 2017, 'Y no Se Ría, Concejal,' Semana, 13 June. Online, available: https://www.semana.com/opinion/ articulo/senador-ramon-cardona-dijo-que-las-leyes-como-las-mujeres-estan-hechas-para-violarlas/528412 [Accessed 12 August 2020].

Mora, L. 2020, 'En Primera Persona,' Arcadia, 6 July. Online, available: https://www.revistaarcadia.com/cine/articulo/enprimera-persona/82081 [Accessed 12 August 2020]. 
U T S

e PRES S

National Women's Network (NWW), 'Cero Violencia contra las Mujeres.' Online, available: $\underline{\text { https:// }}$ rednacionaldemujeres.org/index.php/2015-03-25-19-09-43/cero-violencia-contra-las-mujeres [Accessed 12 August 2020].

Nieto López, J. 2020, 'Cuarenta y Siete Mujeres,' Portal Universitario, Universidad de Antioquia, 7 July. Online, available: http:/www.udea.edu.co/wps/portal/udea/web/inicio/udea-noticias/udea-noticia/!ut/p/z0/ fY4xD4JADIX igsj6al46kgcTIyDgzFwi2mg0SLcAVeM nsPHYyLS9Pv9b2XgoEMjMU7X1DYWawD50afVvNbJomaq90olWqD8liOdvOjycFOzD DaGBq64zKZjCWaGHQNa6XrAeSsJlof-lq2vos49zYp1wwegj9U5bLt3osquZRt-DfcBe7KC8TP2TEJxM1TUk4f2ZvIX1AP3EQ!!/ [Accessed 9 November 2020].

Noticias Caracol. 2020, “Hay Más Mujeres Víctimas de Violencia que Contagiadas de Coronavirus”: Concejala en Medellín,' Noticias Caracol, 3 June. Online, available: https://noticias.caracoltv.com/antioquia/hay-mas-mujeresvictimas-de-violencia-que-contagiadas-de-coronavirus-concejala-en-medellin?00000171-f5e2-d349-a37f$\underline{\mathrm{f} f \mathrm{fe} 57570000 \text {-page }=2}$ [Accessed 12 August 2020].

Observatorio Feminicidios Colombia (OFC). 2020, 'Vivas Nos Queremos: Dossier Cuarentena,'July. Online, available: http://www.observatoriofeminicidioscolombia.org/ [Accessed 12 August 2020].

Restrepo, L. 2016, 'Amor Sin Pies Ni Cabeza,' Pecado. Alfaguara, Bogotá, pp. 301-342.

Restrepo, L. 2018, Los Divinos. Alfaguara, Bogotá.

Ruiz-Navarro, C. \& De los Milagros Londoño, M. 2020, 'Ocho Denuncias de Acoso y Abuso Sexual contra Ciro Guerra,' Volcánicas, 24 June. Online, available: https://volcanicas.com/2020/06/24/ocho-denuncias-de-acoso-y-abusosexual-contra-ciro-guerra/ [Accessed 12 August 2020].

Salcedo, D. 2018, Fragmentos. Installation, recast metal.

Sarralde Duque, M. 2018, “'Sólo el 13 Por Ciento de Feminicidios Tiene Condena”: Naciones Unidas,' 6 December. Online, available: https://www.eltiempo.com/justicia/investigacion/naciones-unidas-advierte-sobre-impunidad-encolombia-en-crimenes-contra-mujeres-300772 [Accessed 12 August 2020].

Segato, R. L. 2016, La guerra contra las mujeres. Traficantes de sueños, Madrid.

Sepúlveda, L. 2020, 'Denuncian al alcalde de La Tebaida, Quindío, por Presunto Abuso Sexual,' El Tiempo, 14 July. Online, available: https://www.eltiempo.com/colombia/otras-ciudades/alcalde-de-la-tebaida-quindio-es-acusado-deabuso-sexual-518090 [Accessed 12 August 2020].

Torres, L. A. n.d., 'Pandemia del feminicidio: 99 mujeres asesinadas en lo corrido de 2020', El Tiempo. Online, available: https://www.eltiempo.com/bogota/pandemia-del-feminicidio-99-mujeres-asesinadas-en-lo-corrido-del-2020-509910 [Accessed 12 August 2020].

UN Women. 2020, 'Violence against Women and Girls: The Shadow Pandemic,' 6 April. Online, available: https:// www.unwomen.org/en/news/stories/2020/4/statement-ed-phumzile-violence-against-women-during-pandemic [Accessed 12 August 2020].

Verdad Abierta (VA). 2017, 'Ligerezas Verbales del Ministro de Defensa Exponen a Líderes Sociales,' 20 December. Online, available: https://verdadabierta.com/ligerezas-verbales-del-ministro-de-defensa-exponen-a-lideres-sociales/ [Accessed 12 August 2020]. 